\title{
Beyond performativity, how and why American courts should not have used Efficient market hypothesis.
}

Franck Jovanovic, TELUQ, LÉO - Université d'Orléans, CIRST

In Isabelle Chambost, Marc Lenglet and Yamina Tadjeddine eds. (2017)

\begin{abstract}
This article provides a critical perspective on the performativity of the Efficient Market Hypothesis. It showed that this hypothesis is a fiction that created a hyper-reality rather than performed financial markets. Its use by practitioners, particularly courts and judges in the United States, has created a dialogue of deaf and has generated a gap between the observation of real financial markets and the reality practitioners and academics observe from this fiction. This gap has created and fuelled several misunderstandings discussed in this article.
\end{abstract}

This article provides a critical perspective on the performativity of the Efficient Market Hypothesis (EMH) by studying its use by practitioners, particularly courts and judges in the United States; then it analyses the dialogue of deaf this use has created. EMH was formulated in the period from 1959 to 1976 to give a theoretical explanation to the random character of stock market prices. The EMH was proposed on the intuition that a pure random-walk model would verify two properties of competitive economic equilibrium: the absence of marginal profit and the equalisation of a stock's price and value. Thus, its initial formulation suggested that stock prices fully reflect all available information, and that, consequently, the actual price of a security is equal to its intrinsic value. In addition, because new information is supposed to arrive randomly, stock prices fluctuate randomly. EMH laid down one of the cornerstones of financial economics and the importance of the pure random-walk model and the Gaussian distribution (Poitras 2006, Poitras and Jovanovic 2007, 2010, Rubinstein 1975, Sewell 2011): validating the random nature of stock-market variations would, in effect, establish that prices on competitive financial markets are in permanent equilibrium as a result of the effects of competition (Jovanovic 2008). This is what the EMH should be: the random character of stock market variations would demonstrate that the prices reflect the competitive equilibrium by incorporating the available information.

In 1996, two economists, Houthakker and Williamson, tested the random character of stock prices during three periods: January 1969 to June 1975; July 
1975 to June 1982; July 1982 to June 1992. They concluded that "the stock market, as measured by the S\&P500, did not follow a random walk during the first two periods but did so in the third period. In other words, the market became more efficient over years" (Houthakker and Williamson 1996, 136). They added, "it is somewhat ironic that in the 1970s, when the EMH gained widespread acceptance, there were significant departures from a random walk. Fortunately for financial theory -and for the functioning of our capital markets- the market now conforms closely to a random walk. Reality has caught up with theory". In a certain way, which will be clarified thereafter, these authors provide a telling example on how financial economics, and particularly $\mathrm{EMH}$, has not merely described or explained but also actively shaped financial markets and practices. This is precisely the way performativity is most commonly understood (Boldyrev and Svetlova 2016).

The performativity of financial economics has been well analysed and documented (Boldyrev and Svetlova 2016, MacKenzie 2006, MacKenzie, Muniesa, and Siu 2007, MacKenzie and Millo 2003, Mason, Kjellberg, and Hagberg 2015). Following the perspective opened by this literature, this article argues that $\mathrm{EMH}$ leads to the creation of a fiction, and by trying to shape the real financial markets from this fiction, practitioners and academics have generated a gap between the observation of real financial markets and the reality they observe from this fiction. This gap has increased, creating and fuelling several misunderstandings between on the one hand financial economists and on the other hand academics and practitioners trained in other fields, like lawyers ${ }^{1}$. Moreover, from Le Gall (2008), Gordon (2013) and Schinckus (2016), this article sheds some lights on these misunderstandings by discussing the "financial reality" created by financial economists from $E M H$, suggesting that beyond the possible performativity of $\mathrm{EMH}$, these misunderstandings can reflect the coexistence of several realities or a hyper-reality which is "the generation by models of a real without origin or reality" (Baudrillard 1994, 1).

\section{The creation of performative fiction}

Efficient market is a very well known term in finance, widely used by academics and practitioners. EMH constitutes one of the major theoretical foundations of the financial economics' framework (Fama 1991, Jovanovic 2010, Jovanovic and Schinckus 2016, Malkiel 1992, Poitras 2009, Zuckerman 2013). In 2013, the "Nobel Prize in economics" was awarded to Eugene Fama, mainly for his work related to this hypothesis:

"In the 1960s, Eugene Fama demonstrated that stock price movements are impossible to predict in the short-term and that new information affects prices almost immediately, which means that the market is efficient. The impact of Eugene Fama's, results has extended beyond the field of

\footnotetext{
${ }^{1}$ We could also mention econophysicists for instance (Schinckus 2016, 7).
} 
research. For example, his results influenced the development of index funds" (http://www.nobelprize.org/nobel_prizes/economicsciences/laureates/2013/fama-facts.html).

Despite this claim, we must clarify Fama's contribution. Given that several authors demonstrated the unpredictability of stock price movements before the 1960s (Jovanovic and Le Gall 2001, Jovanovic 2009, 2010, Poitras and Jovanovic 2007, Sewell 2011), Fama's major contribution concerns the introduction of the term of "efficient market" and the affirmation according to which "new information affects prices almost immediately" (Jovanovic 2010, 2008). EMH has largely shaped financial markets and practices. Among the telling examples, we can mention its use for implementing the computerization of financial markets (Schinckus 2008), the international standardization of accounting conventions (Chane-Alune 2006, Miburn 2008), the legal policies in U.S. (Fischel 1989a, Hammer and Groeber 2007, Jovanovic et al. 2015, Langevoort 2009) or the financial regulation policies (Muniesa 2003, PardoGuerra 2015); EMH has also changed trading practices (MacKenzie 2006, Schinckus 2016), particularly the equities managed by institutional investors like exchange-traded fund ${ }^{2}$. Given the influence of this hypothesis on real financial markets and practices, we could view this hypothesis as a telling example of performativity (Brisset 2016, MacKenzie 2006).

While, the performativity of this hypothesis seems obvious, it is, in a certain way, highly paradoxical. Indeed, the EMH is hardly testable because any empirical test of this hypothesis refers to what it is called in the literature, a joint-test. A jointtest refers to the fact that, on a given market, any test of the efficiency (i.e. the fact prices fully reflect available information) tests at the same time the notion of efficiency and the asset-pricing model used to price securities on this market. In other words, any empirical refutation (or validation) can be due either to the fact that the market is not efficient (or efficient) or that the model used is not appropriate (or appropriate) for the test. In other words, such a joint-test implies that market efficiency per se is not testable (Campbell, Lo, and MacKinlay 1997, Cuthbertson 2004, Fama 1976, Jovanovic 2010, LeRoy 1976, 1989, Lo 2000). Consequently, the observation on a financial market of the random character of stock price or return (i.e. are impossible to predict) does not guaranty that the EMH is validated (Cornell 2013, Cutler, Poterba, and Summers 1989, De Meyer and Moussa Saley 2003, Longin 1996) ${ }^{3}$. This result is supported by another major drawback of this hypothesis: the demonstration between the EMH and the main stochastic process (martingale), provided by Fama (1970) is tautological and questionable (LeRoy 1976, 1989).

Despite this paradoxical situation, EMH has kept a strong influence among financial economists, and the whole financial economics mainstream is based on

\footnotetext{
${ }^{2}$ An exchange-traded fund is an investment fund trades on financial markets and that tracks an index.

${ }^{3}$ It is also true for the other methods used for testing EMH.
} 
this hypothesis (CAPM, Black and Scholes option pricing model, Harrison-KrepsPliska theoretical framework, etc.). This scientific survival is certainly not estranged from the methodological foundations of this hypothesis. The latter is based on Milton Friedman's positivism according to which the realism of the hypotheses has no relevance in judging the validity of a model because its predictions are all that really matters (Crotty 2013, Frankfurter and McGoun 1996, 1999, Friedman 1953, Findlay and Williams 2001). In the case of EMH, the predictions are the consequence of a competitive market, such as the noarbitrage opportunity or the no-profit opportunity. Consequently, EMH does not pretend to provide a description of real markets. However, focusing on the predictions and the empirical tests, the lack of realism of this hypothesis has created the proliferation of definitions leading to the lack of a consensual meaning of this hypothesis. For instance, according to Fama $(1970,383)$ "a market in which prices always "fully reflect" available information is called "efficient"'; on the other hand, Fama et al. (1969) defined an efficient market as "a market that adjusts rapidly to new information"; Jensen (1978) considered that "a market is efficient with respect to information set $\theta_{t}$ if it is impossible to make economic profit by trading on the basis of information set $\theta_{t}$; ; according to Malkiel (1992) "the market is said to be efficient with respect to some information set [...] if security prices would be unaffected by revealing that information to all participants. Moreover, efficiency with respect to an information set [...] implies that it is impossible to make economic profits by trading on the basis of [that information set]"; Malkiel (2003) stated that efficient financial markets "do not allow investors to earn above-average returns without accepting above-average risks". Harrison and Kreps (1979) and Harrison and Pliska (1981) associated the efficiency with the arbitrage-free. These definitions are clearly different. Given the lack of consensual definition of what efficient financial markets are, nobody knows what an efficient market should be! Only a consensus can be found on its possible consequences, such as the no-profit, no-arbitrage opportunity, or the no-predictability.

To sum up, EMH is a fiction and not a description of real financial markets. This fiction was built from what a financial competitive market should be in order to mimic the idealistic framework of economics. This fiction has performed financial markets thanks to the implementation of some of its logical consequences in regulations, conventions, computerization and practices. However, because this hypothesis cannot be tested per se, we cannot provide a quantitative measure of the efficiency of a financial market, as Houthakker and Williamson (1996) suggested ${ }^{4}$. Consequently, this performativity seems to be evaluated only through the way new regulations, computerisation rules, or laws are implemented. Fraud on the Market Doctrine (FoMD), also called Fraud on the Market Theory, is one telling example of such performativity due to the fact that

\footnotetext{
${ }^{4}$ We could argue that if we define the efficiency as the no-arbitrage opportunity, as Harrison and Kreps (1979) and Harrison and Pliska (1981), we could estimate the efficiency on foreign exchange markets for instance. Such exceptions are rare and supposed to use a definition of EMH different from that of Fama's and that does not refer to the information.
} 
U.S. courts have used EMH for creating a new jurisprudence about this doctrine. The next part details and discusses this point.

\section{Some consequences of the use of EMH fiction by U.S. courts}

EMH has played a key role in Fraud on the Market U.S. Doctrine by changing its interpretation and its scope. The legal roots of this doctrine can be traced back to the first attempts to safeguard financial markets as well as the interests of investors from fraud and manipulation after the 1929 stock market crash. Initially, this doctrine required plaintiffs (i.e. investors) to provide evidence of an intentional misstatement or omission of a material fact on which they had relied and which had been the proximate cause of their injury. Since 1980 U.S. courts have used the EMH for changing the FoMD in order to open the door to class action lawsuits (Gordon 2013, Jovanovic et al. 2015). A securities fraud case will therefore typically involve a debate around whether or not the market in which the securities were traded, was efficient, with the plaintiffs (investors) trying to demonstrate this efficiency and the defendants (generally officers of the company) trying to disprove it. U.S. courts referred directly to the EMH to justify the introduction of this presumption in the court system in order to strengthen the case for class actions in securities fraud litigation. In this perspective, the EMH is used for demonstrating that every fraudulent misrepresentation was necessarily reflected in stock prices, and that every investor could rely solely on those prices for transacting. Courts were therefore justified in relinquishing the requirement of direct reliance on the alleged misrepresentation whenever public information could have an automatic influence on prices.

In their demonstration, U.S. courts radically changed the interpretation of the FoMD thanks to the EMH definition introduced by Fama (1970). However, by using Fama's definition, they seemed to (voluntarily) ignore or underestimate the fact that market efficiency per se is not testable, has a polymorphous definition, is a fiction, and doesn't designate real financial markets. As Gordon $(2013,10)$ explained "when the law is using a hypothesis to settle a fact, that may be one indication that we are in the presence of a fiction". "The fiction here is that its version of the fraud-on-the-market theory pivots on the Court's belief that the efficient-market hypothesis not only reflects reality but that there was general agreement at the time that this was so" (Gordon 2013, 8). It is worth mentioning that, according to this author, some Judges and courts were aware that market efficiency is a fiction. However, they probably underestimated all of the consequences of such a performativity based on a fiction when they had to analyse a real fraud. However, it is worth mentioning that there is a sole interpretation among courts and judges. As Jovanovic et al. (2015) explained, considering the impossible validation of the $\mathrm{EMH}$, several courts used a less literal definition of efficiency stipulating that prices must reflect "most" (and not "fully" reflect "all") public information as Fama (1970) claimed. For instance in PolyMedica (2004 and 2005), the court considered that an efficient market 
"is simply one in which 'most publicly announced material statements about companies' affect stock market prices". In response to this definition of market efficiency, the defendant appealed, alleging an error of law arising from the use of "most" in the definition of efficiency, instead of "all" and "fully" (Jovanovic et al. $2015,185)$. The practical difficulties inherited from market efficiency definition led the Supreme Court of U.S. to take position for a second time about the FoMD in June 2014. Indeed, while this definition using "most" is easier to satisfy, it opened the door to criticisms according to which lawyers were said to have initiated class action suits as soon as they saw a significant drop in the stock price of a company, and it is only afterwards that they are looking for evidence of fraud (Erdlen 2011, 897). In 1995, the Congress responded to these criticisms by adopting a major reform of securities law that was expressly aimed at holding back class action suits (Oldham 2003). This reform did not stop the controversy, and harsh debates still continued between the district courts, the Court of Appeal and the Supreme Court about the definition of market efficiency. The last judgement of the Supreme Court of U.S. shows that "Securities class actions are here to stay" (insidecounsel.com - September 2014, 11), recognizing the legal reality created by the use of the EMH inherited from Fama (1970) (Jovanovic et al. 2015).

It is worth analysing the controversy between "most" and "all/fully". This controversy reveals that U.S. courts refer to two realities although they did not mention it: the use of the term "most" directly refers to the real financial markets while the use of terms "all" and "fully" are directly related to the EMH fiction". Indeed, the definition using the term "most" is crafted for the practical legal purpose guarantying the applicability of the FoMD (Jovanovic et al. 2015). In this case, courts interpret real financial markets. By opposition, the definition using the terms "full" and "all", courts interpret a fiction. Indeed, as explained, the observation of a full reflection of all available information does not exist in real financial markets. This no-existence is at least the logical consequence of the lack of demonstration between EMH definition stated by Fama (1970) and the hypotheses that are really tested (no-profit, arbitrage free, etc.). In other terms, the paradoxical situation pointed out in the first part has led to a deaf dialogue between the U.S. courts because they based their demonstrations and interpretations on two incompatible realities.

This result calls for a new look on the performativity of $\mathrm{EMH}^{6}$. Remember that the performativity supposes to have access to the real financial markets, because performativity implies that EMH actively shapes the real markets. Discussing the computerization of financial markets, Schinckus (2016) suggests that while the

\footnotetext{
${ }^{5}$ The controversy between "most" and "all/fully" is not the only one created by the use of EMH. Jurists introduced for instance a dual definition of market efficiency depending on the importance given to the notion of fundamental value, leading to distinguish between a "trading-rule efficiency" and a "value efficiency" (Fischel 1989b, 912-13).

${ }^{6}$ See also the position defended by Zuckerman (2013) about the performativity of EMH.
} 
relation between EMH and real financial market does not exist, a relation exists between the $\mathrm{EMH}$ and a hyper-reality created from this hypothesis:

"Computerization of the financial sphere is based on an a priori representation (the efficient-market hypothesis) that does not exist outside our textbooks [...]. This hyper-reality enhanced by the computerization of financial markets does not result from potential reality (efficient market do not exist), but paradoxically shapes reality" (Schinckus 2016, 5).

Following this point, the EMH hyper-reality has replaced the real financial markets, which are not accessible anymore. In this perspective, this hyper-reality is not plainly compatible with the idea of performativity because it is not the real financial markets that are shaped. Considering our previous discussion, by using "fully/all" to define the efficiency, efficient market becomes a hyper-reality for courts (i.e. an imaginary projection of what is a market) from which they extended the FoMD. Judging the "real" markets from this "imaginary construction of financial markets" (Schinckus 2016, 7) could appear paradoxical, but it is not! Given that efficient market hypothesis is used in order to open a class action lawsuit, showing statistical data proving that stock prices or returns are stochastic, is supposed to validate the $\mathrm{EMH}^{7}$, and to prove the market efficiency for the tenants of the EMH hyper-reality. Doing this is generally enough to find a deal between the two parts and then to stop the lawsuit without making a real demonstration that markets are efficient. Therefore, a real confrontation with real financial markets never occurs. In other term, the FoMD extended with EMH has allowed the existence of two realities and the maintenance of the deaf dialogue previously pointed out.

\section{Conclusion}

This article showed that EMH is a fiction that created a hyper-reality rather than performed financial markets. The fact that some courts interpret a fiction and other courts interpret the real markets has some practical implications. According to the definition of EMH and then the reality (i.e. real markets or hyper-reality) in which the courts will base their interpretations, we can have more or less class action lawsuits: if we interpret the reality ("most") we will increase number of class action lawsuits, by opposition if we interpret the hyper-reality ("full/all") we will decrease number of class action lawsuits.

\footnotetext{
${ }^{7}$ We have the same result if we use any other statistical tests that validate one of the three forms of the EMH.
} 


\section{References}

Baudrillard, Jean. 1994. Simulacra and simulation. Ann Arbor: University of Michigan Press.

Boldyrev, Ivan, and Ekaterina Svetlova, eds. 2016. Enacting Dismal Science. New Perspectives on the Performativity of Economics. New York: Palgrave Macmillan.

Brisset, Nicolas. 2016. "Economics Is not Always Performative: Some Limits for Performativity." Journal of Economic Methodology 23 (2):160-184.

Campbell, John Y., Andrew W. Lo, and Archie Craig MacKinlay. 1997. The econometrics of financial markets. Chichester;Princeton, N.J;: Princeton University Press.

Chane-Alune, Elena. 2006. Accounting Standardization and Gouvernance Structures. In Working paper $n^{\circ} 0609$, University of Liège.

Cornell, Bradford. 2013. "What moves stock prices: another look." Journal of Portfolio Management 39 (3):32.

Crotty, James R. 2013. "The Realism of Assumptions Does Matter: Why Keynes-Minsky Theory Must Replace Efficient Market Theory as the Guide to Financial Regulation Policy." In The handbook of the political economy of financial crises, edited by Martin H. Wolfson and Gerald A. Epstein, 133-158. New York, NY: Oxford University Press.

Cuthbertson, Keith. 2004. Quantitative financial economics: stocks, bonds, and foreign exchange. Chichester: John Wiley.

Cutler, David M., James M. Poterba, and Lawrence H. Summers. 1989. "What moves stock prices?" Journal of Portfolio Management 1 (5):4-12.

De Meyer, Bernard, and Hadiza Moussa Saley. 2003. "On the Strategic Origin of Brownian Motion in Finance." International Journal of Game Theory 31:285-319.

Erdlen, Andrew M. 2011. "Timing Is Everything: Markets, Loss, and Proof of Causation in Fraud on the Market Actions." Fordham Law Review 80:877.

Fama, Eugene F. 1970. "Efficient Capital Markets: A Review of Theory and Empirical Work." Journal of Finance 25 (2):383-417.

Fama, Eugene F. 1976. "Efficient Capital Markets: Reply." Journal of Finance 31 (1):143-145.

Fama, Eugene F. 1991. "Efficient Capital Markets: II." Journal of Finance 46 (5):15751617.

Fama, Eugene F., Lawrence Fisher, Michael C. Jensen, and Richard Roll. 1969. "The Adjustment of Stock Prices to New Information." International Economic Review $10(1): 1-21$.

Findlay, M. Chapman, and Edward E. Williams. 2001. "A Fresh Look at the Efficient Market Hypothesis: How the Intellectual History of Finance Encouraged a Real "Fraud-on-the-Market"." Journal of Post Keynesian Economics 23 (2):181-199.

Fischel, Daniel R. 1989a. "Efficient Capital Markets, the Crash, and the Fraud on the Market Theory." Cornell Law Review 74:907.

Fischel, Daniel R. 1989b. "Symposium on the regulation of secondary trading markets: program trading, volatility, portfolio insurance, and the role of specialists and market makers: efficient capital markets, the crash, and the fraud on the market theory." Cornell Law Review 74:907-922.

Frankfurter, George M., and Elton G. McGoun. 1996. Toward Finance With Meaning, The Methodology of Finance: What It Is and What It Can Be. Greenwich (Connecticut): Jai Press.

Frankfurter, George M., and Elton G. McGoun. 1999. "Ideology and the Theory of Financial Economics." Journal of Economic Behavior \& Organization 39:159177. 
Friedman, Milton. 1953. Essays in positive economics. Chicago: The University of Chicago Press.

Gordon, Randy D. 2013. "Fictitious fraud: economics and the presumption of reliance." International Journal of Law in Context 9 (4):506.

Hammer, Howard M., and Ronald X. Groeber. 2007. "Efficient market hypothesis and class action securities regulation." International Journal of Business Research 1:1-14.

Harrison, J. Michael, and David M. Kreps. 1979. "Martingales and arbitrage in multiperiod securities markets." Journal of Economic Theory 20 (3):381-408.

Harrison, J. Michael, and Stanley R. Pliska. 1981. "Martingales and Stochastic Integrals in the Theory of Continuous Trading." Stochastic Processes and their Applications 11 (3):215-260.

Houthakker, Hendrik S., and Peter J. Williamson. 1996. The economics of financial markets. New York: Oxford University Press.

Jensen, Michael C. 1978. "Some anomalous evidence regarding market efficiency." Journal of Financial Economics 6 (2-3):95-101.

Jovanovic, Franck. 2008. "The Construction of the Canonical History of Financial economics." History of Political Economy 40 (2):213-242.

Jovanovic, Franck. 2009. "Le modèle de marche aléatoire dans l'économie financière de 1863 à 1976." Revue d'Histoire des Sciences Humaines 20:81-108.

Jovanovic, Franck. 2010. "Efficient markets theory." In Encyclopedia of Quantitative Finance, edited by Rama Cont. Chichester (UK): John Wiley \& Sons.

Jovanovic, Franck, Stelios Andreadakis, Christophe Schinckus, and Pascale Cornut StPierre. 2015.

Jovanovic, Franck, and Philippe Le Gall. 2001. "Does God practice a random walk? The "financial physics" of a 19th century forerunner, Jules Regnault." European Journal for the History of Economic Thought 8 (3):323-362.

Jovanovic, Franck, and Christophe Schinckus. 2016. Econophysics for financial economics. New York: Oxford University Press.

Langevoort, Donald C. 2009. "Basic at Twenty: Rethinking Fraud on the Market." Wisconsin Law Review 2009:151-198.

Le Gall, Philippe. 2008.

LeRoy, Stephen F. 1976. "Efficient Capital Markets: Comment." Journal of Finance 31 (1):139-141.

LeRoy, Stephen F. 1989. "Efficient Capital Markets and Martingales." Journal of Economic Literature 27 (4):1583-1621.

Lo, Andrew W. 2000. "Finance: A selective survey." Journal of the American Statistical Association 95 (450):629.

Longin, François M. 1996. "The Asymptotic Distribution of Extreme Stock Market Returns." The Journal of Business 69 (3):383-408.

MacKenzie, Donald A. 2006. An engine, not a camera : how financial models shape markets, Inside technology. Cambridge, Mass.: MIT Press.

MacKenzie, Donald A., Fabian Muniesa, and Lucia Siu, eds. 2007. Do Economists Make Markets? On the Performativity of Economics. Princeton, NJ: Princeton University Press.

MacKenzie, Donald, and Yuval Millo. 2003. "Constructing a Market, Performing Theory: The Historical Sociology of a Financial Derivatives Exchange." American Journal of Sociology 109 (1):107-145.

Malkiel, Burton G. 1992. "Efficient Market Hypothesis." In The New Palgrave Dictionary of Money and Finance, edited by Peter Newman, Murray Milgate and John Eatwell. London: Macmillan. 
Malkiel, Burton G. 2003. "The Efficient Market Hypothesis and Its Critics." Journal of Economic Perspectives 17 (1):59-82.

Mason, Katy, Hans Kjellberg, and Johan Hagberg. 2015. "Exploring the Performativity of Marketing: Theories, Practices and Devices." Journal of Marketing Management $31(1-2): 1-15$.

Miburn, J. Alex. 2008. "The Relationship between Fair Value, Market Value, and Efficient Markets." Acounting Perspectives 7 (4):293-316.

Muniesa, Fabian. 2003. Des marchés comme algorithmes : sociologie de la cotation électronique à la bourse de Paris. Ph.D: Ecole Nationale Supérieures des Mines de Paris.

Oldham, Jeffrey L. 2003. "Taking 'Efficient Markets' Out of the Fraud-on-the-Market Doctrine After the Private Securities Litigation Act." Northern University Law Review 97 (2):995.

Pardo-Guerra, Juan Pablo. 2015. "Evaluation Cultures, Organizational Logics, and the Limits of Financial Regulation." University of Leicester.

Poitras, Geoffrey, ed. 2006. Pioneers of financial economics: Contributions Prior to Irving Fisher. Vol. 1. Cheltenham, UK ; Northampton, MA: Edward Elgar.

Poitras, Geoffrey. 2009. "From Antwerp to Chicago: The History of Exchange Traded Derivative Security Contracts." Revue d'Histoire des Sciences Humaines 20:1150.

Poitras, Geoffrey, and Franck Jovanovic, eds. 2007. Pioneers of financial economics: Twentieth-Century Contributions. Vol. 2. Cheltenham, UK ; Northampton, MA: Edward Elgar.

Poitras, Geoffrey, and Franck Jovanovic. 2010. "Pioneers of Financial Economics: Das Adam Smith Irrelevanzproblem?" History of Economics Review 51 (Winter):4364.

Rubinstein, Mark. 1975. "Securities Market Efficiency in an Arrow-Debreu Economy." American Economic Review 65 (5):812-824.

Schinckus, Christophe. 2008. "The Financial Simulacrum." Journal of Socio-Economics 73 (3):1076-1089.

Schinckus, Christophe. 2016. "Pataphysics of finance: An essay of visual epistemology." Critical Perspectives on

Accounting (http://dx.doi.org/10.1016/j.cpa.2016.08.003).

Sewell, Martin. 2011. History of the Efficient Market Hypothesis. In Research Note, edited by University College London. London.

Zuckerman, Ezra W. 2013. "Market Efficiency: A sociological perspective." In Handbook of the sociology of finance, edited by Alex Preda and Karin Knorr-Cetina, 223249. Oxford: Oxford University Press. 